\title{
Evaluation of the catalytic specificity, biochemical properties, and milk clotting abilities of an aspartic peptidase from Rhizomucor miehei
}

\author{
Ronivaldo Rodrigues da Silva ${ }^{1}$ Tatiane Beltramini Souto ${ }^{2}$ Tássio Brito de Oliveira ${ }^{3}$. \\ Lilian Caroline Gonçalves de Oliveira ${ }^{4} \cdot$ Daniel Karcher $^{4} \cdot$ Maria Aparecida Juliano $^{4}$. \\ Luiz Juliano $^{4}$ • Arthur H. C. de Oliveira ${ }^{5}$ André Rodrigues $^{3} \cdot$ Jose C. Rosa $^{6}$ • \\ Hamilton Cabral ${ }^{2}$
}

Received: 10 February 2016 / Accepted: 28 April 2016 / Published online: 10 May 2016

(C) Society for Industrial Microbiology and Biotechnology 2016

\begin{abstract}
In this study, we detail the specificity of an aspartic peptidase from Rhizomисоr miehei and evaluate the effects of this peptidase on clotting milk using the peptide sequence of $k$-casein (Abz-LSFMAIQ-EDDnp) and milk powder. Molecular mass of the peptidase was estimated at $37 \mathrm{kDa}$, and optimum activity was achieved at $\mathrm{pH}$ 5.5 and $55^{\circ} \mathrm{C}$. The peptidase was stable at $\mathrm{pH}$ values ranging from 3 to 5 and temperatures of up $45{ }^{\circ} \mathrm{C}$ for $60 \mathrm{~min}$. Dramatic reductions in proteolytic activity were observed with exposure to sodium dodecyl sulfate, and aluminum and copper (II) chloride. Peptidase was inhibited by pepstatin A, and mass spectrometry analysis identified four peptide fragments (TWSISYGDGSSASGILAK, ASNGGG-
\end{abstract}

Electronic supplementary material The online version of this article (doi:10.1007/s10295-016-1780-4) contains supplementary material, which is available to authorized users.

Hamilton Cabral

hamilton@fcfrp.usp.br

1 Instituto de Biociências, Letras e Ciências Exatas, Universidade Estadual Paulista "Júlio de Mesquita Filho", São José do Rio Preto, São Paulo, Brazil

2 Faculdade de Ciências Farmacêuticas de Ribeirão Preto, Universidade de São Paulo, Av. do Café, s/n ${ }^{\circ}$ Campus Universitário da USP CEP, Ribeirão Preto, São Paulo 14040-903, Brazil

3 Departamento de Bioquímica e Microbiologia, Universidade Estadual Paulista "Júlio de Mesquita Filho", Rio Claro, São Paulo, Brazil

4 Universidade Federal de São Paulo, UNIFESP, São Paulo, Brazil

5 Faculdade de Filosofia, Ciências e Letras de Ribeirão Preto, Universidade de São Paulo, Ribeirão Preto, São Paulo, Brazil

6 Faculdade de Medicina de Ribeirão Preto, Universidade de São Paulo, Ribeirão Preto, São Paulo, Brazil
GEYIFGGYDSTK, GSLTTVPIDNSR, and GWWGITV DRA), similar to rhizopuspepsin. The analysis of catalytic specificity showed that the coagulant activity of the peptidase was higher than the proteolytic activity and that there was a preference for aromatic, basic, and nonpolar amino acids, particularly methionine, with specific cleavage of the peptide bond between phenylalanine and methionine. Thus, this peptidase may function as an important alternative enzyme in milk clotting during the preparation of cheese.

Keywords Aspartic protease - Biochemical characterization $\cdot$ Intramolecularly quenched fluorogenic substrate $\cdot$ Rhizomucor miehei $\cdot$ Specificity

\section{Introduction}

Peptidases constitute the most important subclass of hydrolases and have a variety of applications in numerous fields, leading many researchers to study the production and purification of new proteolytic enzymes $[8,20,23]$. In this context, catalytic specificity studies are important for active site mapping and to determine the hydrolysis preference and mode of action of peptidases [25].

Aspartic peptidase is an acid endopeptidase (E.C. 3.4.23) with two aspartic acid residues at the active site, which are essential for its catalytic performance. This enzyme is employed in several industrial areas, such as cheese manufacturing, casein hydrolysates, peptide synthesis, and degradation of turbidity in protein complexes from fruit juice [29].

Microbial aspartic peptidases can be used as a substitute for chymosin isolated from newborn ruminants. This enzyme (chymosin) is essential for cheese manufacturing 
and is known to cleave the peptide bond between Phe ${ }^{105}$ and $\mathrm{Met}^{106}$ on the polypeptide chain of $k$-casein, a crucial step in milk clotting [14]. However, the extraction of chymosin from young ruminants is associated with ethical problems; thus, microbial production is an attractive, due to the low cost and rapid alternative to support the demand for this enzyme [12, 14].

Mucor spp. and Rhizomucor spp. are fungal producers of aspartic peptidases. Rhizomисо miehei is a thermophilic fungus and rennin-like producer that has a variety of industrial applications [29]. Therefore, in the current study, we purified the aspartic peptidase from $R$. miehei and characterized its biochemical properties and catalytic specificity using an intramolecularly quenched fluorogenic substrate and analysis of clotting milk performance. Our work provides important insights into the catalytic specificity and possibility applications of this aspartic peptidase, has been for the first time, a comprehensive mapping of the catalytic subsites of this enzyme.

\section{Materials and methods}

\section{Microorganisms and maintenance medium}

The fungus $R$. miehei was isolated from decaying wood found in the soil and was cultivated and maintained on potato-dextrose agar slants at $45{ }^{\circ} \mathrm{C}$ for $168 \mathrm{~h}$ to allow for complete growth.

\section{Submerged fermentation (SmF)}

Peptidase production was carried out using $\mathrm{SmF}$ in $250 \mathrm{~mL}$ Erlenmeyer flasks containing $50 \mathrm{~mL}$ liquid media with the follow components (w/v): $0.7 \% \mathrm{KH}_{2} \mathrm{PO}_{4}$, $0.2 \% \quad \mathrm{~K}_{2} \mathrm{HPO}_{4}, 0.01 \% \mathrm{MgSO}_{4} \cdot 7 \mathrm{H}_{2} \mathrm{O}, 0.05 \%$ citrate $2 \mathrm{H}_{2} \mathrm{O}, 0.1 \%$ yeast extract, $0.01 \% \mathrm{CaCl}_{2} \cdot 2 \mathrm{H}_{2} \mathrm{O}$, and $0.5 \%$ casein [27]. The $\mathrm{pH}$ of the medium was adjusted to 5.0 , and the flasks were autoclaved for $15 \mathrm{~min}$ at $121^{\circ} \mathrm{C}$. Inoculation was performed using $1 \mathrm{~mL}$ of mycelial suspension in synchronized growth. After $24 \mathrm{~h}$ of fermentation, the fermentation flasks were removed, and the material was filtered with Whatman No. 1 and centrifuged at $8,000 \mathrm{~g}$ for $20 \mathrm{~min}$ at $4{ }^{\circ} \mathrm{C}$. The supernatant was then used to quantify proteolytic activity and for subsequent chromatographic studies.

\section{Protein content}

The protein content was measured according to the method of Bradford [3] using bovine serum albumin as a standard.
Determination of proteolytic activity and concentration of crude enzymatic extract

Determination of proteolytic activity was performed according to the protocol described by Sarath et al. [24] with modifications. The reaction mixture was composed of $1 \mathrm{~mL}$ of $1 \%(\mathrm{w} / \mathrm{v})$ casein (Sigma, St. Louis, MO, USA) in a $0.05 \mathrm{M}$ monobasic sodium phosphate buffer at a $\mathrm{pH} 6.5$ and $0.2 \mathrm{~mL}$ of the enzyme solution. The reaction was carried out at $45{ }^{\circ} \mathrm{C}$ and stopped with the addition of $0.6 \mathrm{~mL}$ of $10 \%$ trichloroacetic acid (TCA) after $120 \mathrm{~min}$. The reaction tubes were then centrifuged at $10,000 \times g$ for $15 \mathrm{~min}$ at $25{ }^{\circ} \mathrm{C}$, and the absorbance of the supernatant was measured using a spectrophotometer at $280 \mathrm{~nm}$. Each reaction tube presented an appropriate control tube, in which TCA was added before the enzymatic solution. One activity unit (AU) was defined as the amount of enzyme required to liberate $1 \mu \mathrm{M}$ tyrosine/min under the assay conditions [18].

Milk-clotting activity (MCA) was determined using $10 \%(\mathrm{w} / \mathrm{v})$ milk powder in the presence of $0.01 \mathrm{M} \mathrm{CaCl}_{2}$ at $40{ }^{\circ} \mathrm{C}[1,16]$. One milk clotting unit (MCU) was defined as the amount of enzyme required to clot $1 \mathrm{~mL}$ of substrate in $40 \mathrm{~min}$, according to the following equation:

$U=2400 / T \times \mathrm{DF}$

where $T$ is the time of curd formation (s), and DF is the dilution factor (milk volume/enzyme volume) [16, 22].

The total volume of the crude enzyme extract from $\mathrm{SmF}$ was concentrated and partially purified using a Flex Stand System (GE Healthcare), and the filtration of the fermentative extract was performed using a hollow fiber membrane $(10 \mathrm{kDa})$. During the concentration process, the sample was maintained prechilled at $4{ }^{\circ} \mathrm{C}$.

\section{Chromatography}

The crude enzyme extract from $R$. miehei was subjected to size-exclusion chromatography using a Sephadex G-50 resin and a Sephacryl S-100 resin column $(100 \mathrm{~cm} \times 4 \mathrm{~cm})$ sequentially. The resins were equilibrated with a 1.5 column volume, and a flow rate of $0.6 \mathrm{~mL} / \mathrm{min}$ was maintained. Initially, the crude enzyme was applied to Sephadex G-50 resin using acetate buffer $(0.05 \mathrm{M})$ with $0.05 \mathrm{M}$ $\mathrm{NaCl}$ at a $\mathrm{pH}$ of 5.0. Eluted enzyme fractions were examined according to protein content and proteolytic activity and were then evaluated on $12 \%$ polyacrylamide gels by sodium dodecyl sulfate polyacrylamide gel electrophoresis (SDS-PAGE) [15]. Similar fractions were then concentrated by ultrafiltration (Amicon ultrafiltration units) using a $5 \mathrm{kDa}$ membrane filter (Millipore, USA) and applied to Sephacryl S-100 resin using acetate buffer at a $\mathrm{pH}$ of $5.0(0.05 \mathrm{M})$ with $0.15 \mathrm{M} \mathrm{NaCl}$. The protein 
content and proteolytic activity were measured again, and the eluted enzyme fractions were evaluated by SDS-PAGE (12\%) [15]. Analyses of the protein band obtained from SDS-PAGE were performed by staining with silver nitrate according to the methods of See and Jackowski [26], and molecular mass of the peptidase was estimated using the Image Lab 3.0 software (BIO-RAD).

\section{Mass spectrometry}

Identification of the peptidase by mass spectrometry was carried by excision of the band of the purified protein from the SDS-PAGE gel staining with coomassie blue. After that, a successive exchange of $50 \%$ acetonitrile in $0.1 \mathrm{M}$ of ammonium bicarbonate at a $\mathrm{pH}$ of 7.8 , followed by dehydration in acetonitrile and drying using a Speed Vac (Savant, New York, NY, USA). Tryptic digestion was performed using $0.5 \mu \mathrm{g}$ of modified trypsin (Promega Corp., Madison, WI, USA) in $0.1 \mathrm{M}$ ammonium bicarbonate for $18 \mathrm{~h}$ at $37{ }^{\circ} \mathrm{C}$. The reaction was stopped with the addition of $1 \mu \mathrm{L}$ of formic acid. Previously equilibrated in $0.2 \%$ formic acid, the tryptic peptides were then eluted and desalted using micro-tips filled with reverse-phase resin (POROS R2; Perceptive Biosystems, Foster City, CA, USA) [6]. The sample was desalted after two $150 \mu \mathrm{L}$ washes of $0.2 \%$ formic acid and eluted in $30 \mu \mathrm{L}$ of a $60 \%$ methanol $/ 5 \%$ formic acid solution, concentrated in a Speed Vac, and resuspended in $\alpha$-cyano-4hydroxycinnamic acid matrix solution $(5 \mathrm{mg} / \mathrm{mL})$.

Mass spectrometry analysis, two to five microliters of each sample was loaded in a matrix-assisted laser desorption ionization (MALDI) target and analyzed with a MALDI time-of-flight (TOF)-TOF mass spectrometer (Axima Performance; Kratos-Shimadzu, Manchester, UK). The CID-MS/MS spectra from selected protein bands were submitted for protein identification by searching the NCBI database version 57.2 for fungi using MASCOT version 2.2.04. The database search parameters were as follows: trypsin hydrolysis, one missing cleavage allowed, and variable modification for methionine oxidation. The mass tolerance for precursor ions was $1.2 \mathrm{Da}$, and the mass tolerance for fragment ions was set at $0.8 \mathrm{Da}$. Protein identification was supported by the MS/MS analysis of individual ions using CID-MS/MS. Proteins were identified on the basis of at least one peptide if its score was higher than $53(p<0.05)$ or the amino acid sequence was consistently covered by a series of band $y$ type ion fragments [21].

\section{Synthesis of peptides and the determination of cleavage site}

Synthetic substrates were used in this study; fluorescence resonance energy transfer (FRET) peptides were synthesized by the solid phase synthesis method in an automatic peptide synthesizer (Shimadzu Model PSSM-8) [11]. The purification of the peptide series was performed in semipreparative high-performance liquid chromatography (HPLC), and the molecular mass and purity were verified by amino acid analysis and determination of molecular mass with MALDI-TOF mass spectrometry using a microflex-LT mass spectrometer (Brucker-Daltonics, Billerica, MA, USA). Stock solutions of peptides were prepared in DMSO, and their concentrations were determined by a spectrophotometer using the molar extinction coefficient $\lambda_{365 \mathrm{~nm}}=17,300 \mathrm{M}^{-1} \mathrm{~cm}^{-1}[2,11]$.

The scissile bond of hydrolyzed peptides was identified by the isolation of fragments using analytical HPLC followed by the determination of their molecular mass with an LCMS-2020 instrument equipped with an electrospray ionization (ESI) probe (Shimadzu, Tokyo, Japan).

\section{Functional biochemical characterization}

Biochemical characterization studies were performed using the intramolecularly quenched fluorogenic substrate Abz-KLRSSKQ-EDDnp. The enzymatic reaction was carried out by monitoring of fluorescence emission from the hydrolysis of the fluorogenic peptide substrate in a spectrofluorimeter model Lumina fluorescence spectrometer (Thermo Scientific) at $\lambda_{\mathrm{ex}}=320 \mathrm{~nm}$ and $\lambda_{\mathrm{em}}=420 \mathrm{~nm}$.

\section{Effects of $\mathrm{pH}$ and temperature on the activity and stability of the peptidase}

These studies were performed using Abz-KLRSSKQEDDnp as the substrate. The determination of the optimum $\mathrm{pH}$ for peptidase activity was completed at $50{ }^{\circ} \mathrm{C}$ using the following buffers: acetate ( $\mathrm{pH} 4.5$ and 5.0), MES (pH 5.5, 6.0, and 6.5), HEPES (pH 7.0, 7.5, and 8.0), BICINE (pH 8.5 and 9.0), and CAPS (pH 9.5, 10.0, and 10.5), all at $0.1 \mathrm{M}$ and $40^{\circ} \mathrm{C}$. The $\mathrm{pH}$ stability was studied by incubating the peptidase for $1 \mathrm{~h}$ at $25{ }^{\circ} \mathrm{C}$ in different $\mathrm{pH}$ ranges (4.5-10.5). The effects of temperature on peptidase activity were investigated in the range of $35-70{ }^{\circ} \mathrm{C}$, and the effects of temperature on stability (for 5, 30, and $60 \mathrm{~min}$ ) were evaluated in the temperature in the range from 40 to $55^{\circ} \mathrm{C}$ in increments of $5^{\circ} \mathrm{C}$.

\section{Effects of inhibitors and metallic ions on peptidase activity}

For the determination of the mechanism of action of peptidase, according to the protocol described by Dunn [7] with modifications, we used the following inhibitors: iodoacetic acid (IAA), phenylmethylsulfonyl fluoride (PMSF), ethylene-diaminetetraacetic acid (EDTA) each at a final concentration of $5 \mathrm{mM}$, and pepstatin $\mathrm{A}$ at a final concentration of 
Table 1 Summary of the purification of aspartic peptidase from $R$. miehei

\begin{tabular}{lllccc}
\hline Purification step & Total activity $(\mathrm{U})$ & Total protein $(\mathrm{mg})$ & Specific activity $(\mathrm{U} / \mathrm{mg})$ & Fold purification & Yield $(\%)$ \\
\hline Crude extract (SmF) & 1620.0 & 2.60 & 623.0 & 1.0 & 100.0 \\
Concentrated extract & 1080.0 & 1.45 & 745.0 & 1.2 & 66.6 \\
Sephadex G-50 & 215.0 & 0.21 & $1,024.0$ & 1.6 & 13.0 \\
Sephacryl S-100 & 74.0 & 0.07 & $1,057.0$ & 1.7 & 4.5 \\
\hline
\end{tabular}

$0.2 \mathrm{mM}$. Peptidase activity was also evaluated using incubation with the following metal ions at a final concentration of $5 \mathrm{mM}: \mathrm{KCl}, \mathrm{CaCl}_{2}, \mathrm{MgCl}_{2}, \mathrm{CoCl}_{2}, \mathrm{MnCl}_{2}, \mathrm{BaCl}_{2}$, and $\mathrm{AlCl}_{3}$. These experiments were performed at $50{ }^{\circ} \mathrm{C}$ with an acetate buffer $(0.1 \mathrm{M})$ at a $\mathrm{pH}$ of 5.5 and using $\mathrm{Abz}-$ KLRSSKQ-EDDnp as the substrate.

\section{Effects of surfactants, urea, dithiothreitol (DTT), and guanidine on peptidase activity}

The analysis of the effects of surfactants on proteolytic activity was carried out at different concentrations (0.02-1 \%), using the following surfactants: Tween 20, Triton X-100, cetyltrimethylammonium bromide (CTAB), and sodium dodecyl sulfate (SDS). We also examined the effects of urea, DTT, and guanidine at different concentrations $(10,25,50,100$, and $150 \mathrm{mM})$.

\section{Determination of the molar concentration and specificity of the peptidase}

Using specific inhibitor, pepstatin $\mathrm{A}$, the concentration of the active peptidase (final concentration $=5 \mu \mathrm{M}$ ) was quantified by active-site titration [13, 28]. Analyzing the catalytic specificity, we used six series of FRET substrates, i.e., Abz-XLRSSKQ-EDDnp, Abz-KXRSSKQ-EDDnp, Abz-KLXSSKQ-EDDnp, Abz-KLRXSKQ-EDDnp, AbzKLRSXKQ-EDDnp, and Abz-KLRSSXQ-EDDnp, whose combinatorial replacement of amino acids in different positions at $\mathbf{X}$ determined the specificity of each catalytic subsite $\left(S_{3}, S_{2}, S_{1}, S^{\prime}{ }_{1}, S^{\prime}{ }_{2}\right.$, and $\left.S^{\prime}{ }_{3}\right)$ for the amino acids evaluated in each peptide series. Kinetic assays were performed using an acetate buffer $(0.1 \mathrm{M})$ at $\mathrm{pH} 5.5$ and $50{ }^{\circ} \mathrm{C}$. Using nonlinear regression hydrolysis data (GraphPad Prism version 5.0 software), the kinetic parameters $K_{\mathrm{M}}$ and $V_{\max }$ were obtained according to the Michaelis-Menten equation and used to calculate the catalytic efficiency $\left(k_{\mathrm{cat}} / K_{\mathrm{M}}\right)$.

\section{Statistical analyses}

Statistical analyses were performed by the GraphPad Prism version 5.0 software using the analysis of variance (ANOVA). Differences with $p$ values of less than 0.05 were considered significant.

\section{Results}

\section{Peptidase purification}

All purification steps performed to obtain pure peptidase are shown in Table 1. The final yield was $4.5 \%$, with a purification factor of 1.7. Fractionation of crude extract, without the use of saline solution or organic solvent, resulted in a yield of $66.6 \%$.

Initially, the crude extract was subjected to sizeexclusion chromatography using Sephadex G-50, and the chromatograms showed three defined protein peaks (I, II, and III) for absorbance at $280 \mathrm{~nm}$, with proteolytic activity detected for peak II (Fig. 1a). All fractions corresponding to peak II were selected and analyzed by SDS-PAGE $12 \%$. The protein profile exhibited similarities for fractions 68-74; these fractions were pooled and concentrated.

In the second step of purification, the sample was applied to Sephacryl S-100 resin, and the chromatogram showed five protein peaks at $280 \mathrm{~nm}$ absorbance (Fig. 1b). Enzymatic activity was detected in peak II, and SDS-PAGE $12 \%$ showed the presence of the pure peptidase in fractions 75-83; the peptidase had an estimated molecular mass of $37 \mathrm{kDa}$ (Fig. 1c).

\section{Mass spectrometry}

Mass spectrometry analysis was performed by tryptic digestion of the band protein obtained from SDS-PAGE and MALDI-TOF results revealed similarity with the rhizopuspepsin aspartic protease. Fig. 1d showed the amino acids sequence of the rhizopuspepsin precursor (EC 3.4.23.6) from Rhizopus microsporus var. chinensis (NCBI: gil169740; GenBank: AAA33879.1), identified by gel band mass spectrometry analysis. All $b$ and $y$ series ions from 1,799.9, 1,780.81, 1,259.67, and 1,089.51 $\mathrm{m} / \mathrm{z}$ peptides were used to identify the sequences TWSISYGDGSSASGILAK, ASNGGGGEYIFGGYDSTK, GSLTTVPIDNSR, and GWWGITVDRA, respectively. The protein identification presented a MACOT score of 366 and the identified peptides covering $16 \%$ of protein sequence. The rhizopuspepsin calculated isoelectric point is 5.12, and the predicted protein molecular mass is $37,102 \mathrm{Da}$. 

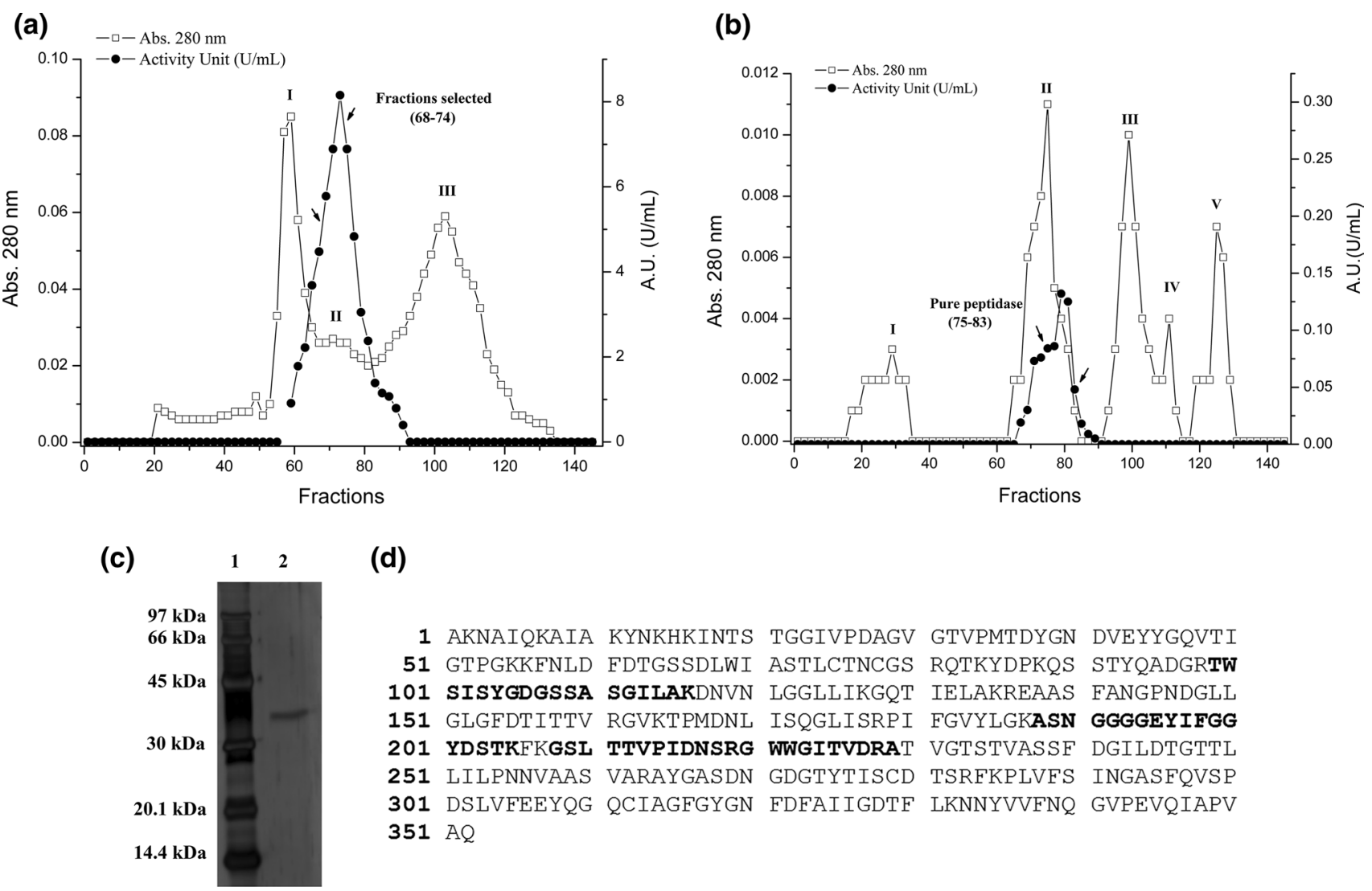

(d)

Fig. 1 Chromatographic profiles of the peptidase purified by gel filtration on Sephadex G-50 resin (a) and Sephacryl S-100 resin (b). SDS-PAGE (12\%) of the pure peptidase (c): line 1 molecular weight

\section{Effects of $\mathrm{pH}$ and temperature on the activity and stability of the peptidase}

Optimization of reaction parameters showed that the enzyme had optimal activity at pH 5.5 (Fig. 2a). The peptidase exhibited the highest activity at an acid $\mathrm{pH}$ and progressive reduction of hydrolysis with increasing alkalinity. Statistical data showed no differences in proteolytic activity at $\mathrm{pH} 4.5,5$, and $6(p=0.43)$, with the enzyme maintaining a catalytic performance around $80 \%$. As shown in Fig. 2a, we also performed kinetic studies (catalytic efficiency) at different $\mathrm{pH}$ using the clotting sequence peptide $k$-casein (Abz-LSFMAIQ-EDDnp) at a temperature of $40{ }^{\circ} \mathrm{C}$. The results showed that the highest catalytic efficiency was obtained at an acidic $\mathrm{pH}$. We also noted a tendency for a low $k_{\text {cat }}$ and high $K_{\mathrm{M}}$, resulting in the reduction of catalytic performance under alkaline conditions.

As shown in Fig. $2 b$, the optimum temperature was $55{ }^{\circ} \mathrm{C}$, and 90 and $80 \%$ proteolytic activities were maintained at 60 and $65{ }^{\circ} \mathrm{C}$. Statistical analysis showed that there were no signification differences within the temperature range of $40-50{ }^{\circ} \mathrm{C}$, at which the relative activity of the markers; line 2 pure peptidase. Protein sequencing analysis (d) and peptide fragment analysis of peptidase from R. miehei (in bold)

peptidase was maintained at around $80 \%(p=0.63)$. Thus, the peptidase exhibited high proteolytic performance at a range of temperatures.

Stability analysis revealed the highest tolerance for acidic $\mathrm{pH}$ values (3-5), maintaining $80 \%$ relative activity at $\mathrm{pH} 5$, with progressive reduction of enzyme activity during incubation under alkaline conditions (for $1 \mathrm{~h}$; Fig. 2c). In addition, the peptidase exhibited the highest thermal stability (70\% residual activity) at temperatures up to $45{ }^{\circ} \mathrm{C}$ after of 60 min incubation, with activity dropping to $40 \%$ of residual activity when incubated at $50{ }^{\circ} \mathrm{C}$ under the same conditions (Fig. 2d).

\section{Effects of metal ions and inhibitors on peptidase activity}

Metal ions are chemical agents that are often capable of influencing the proteolytic activity of peptidases. In this study, we noted reductions in enzymatic activity after incubation with all ions except lithium chloride and sodium chloride, for which enzyme activity was not significantly altered $(p=0.26)$. For the other metal ions, the most 

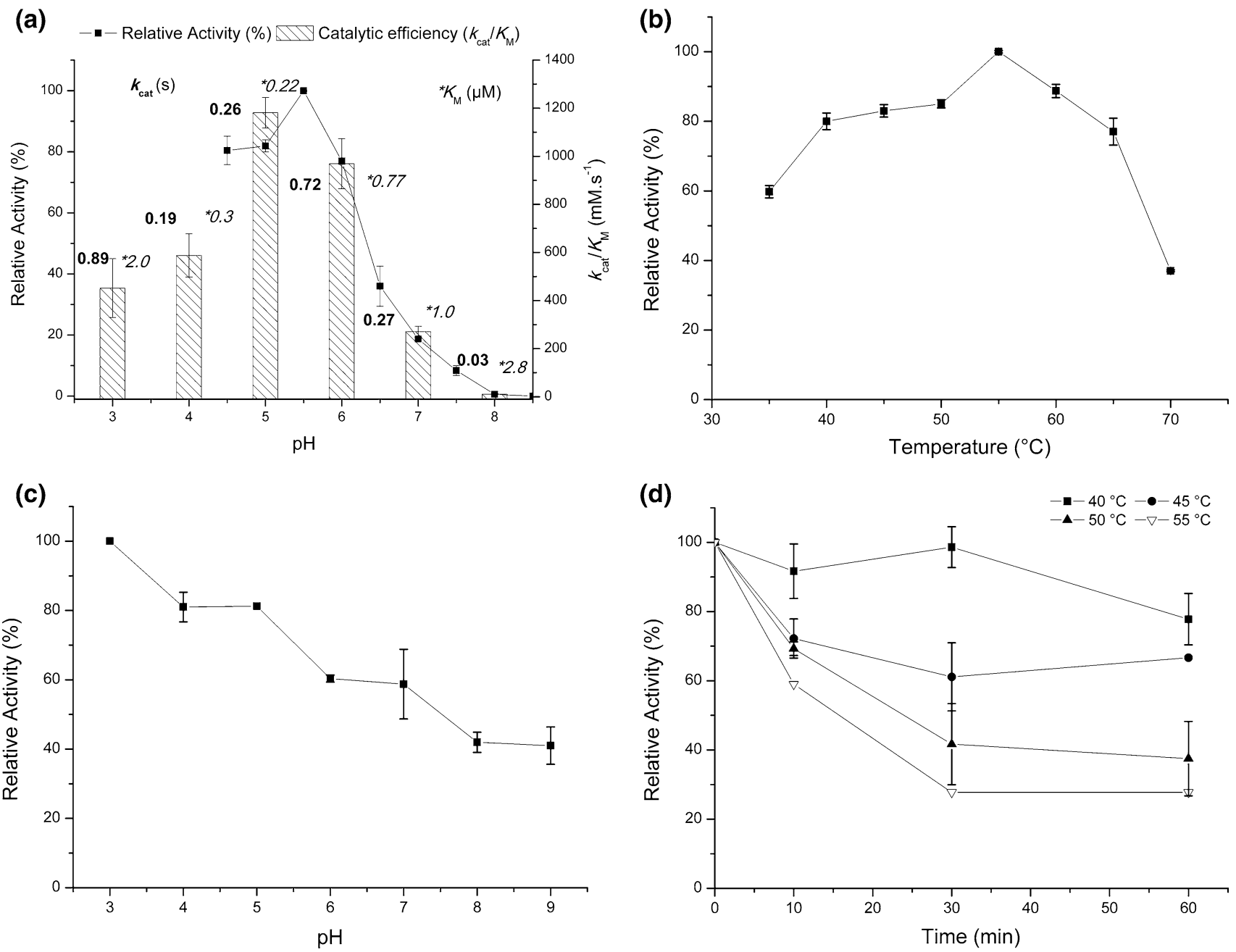

Fig. 2 Effects of pH (a) and temperature (b) on the activity, pH stability (c), and thermal stability (d) of the enzyme

dramatic reductions in proteolytic activity were observed in the presence of aluminum chloride (residual activity $16 \%$ ) and copper (II) chloride (residual activity $0.3 \%$ ). During incubation with cobalt, manganese, and magnesium chloride, the peptidase exhibited residual activity around $36 \%$ ( $p=0.86$ ), whereas for calcium chloride, potassium chloride, and barium chloride, activities of 44, 56, and $64 \%$ were observed.

For the determination of the mechanism of action of the peptidase, we analyzed the effects of IAA, PMSF, EDTA, and pepstatin A. Incubation of the peptidase in the presence of these inhibitors resulted in varying levels of inhibition; the greatest inhibition was observed in the presence of pepstatin A, for which the residual enzyme activity was $40 \%$ at a final concentration of $0.2 \mathrm{mM}$ pepstatin $\mathrm{A}$, indicating that the peptidase examined in our study was an aspartyl (aspartic) or acid peptidase. This is consistent with the known characteristics of $R$. miehei as a producer of aspartic peptidase.

\section{Effects of surfactants, urea, DTT, and guanidine on peptidase activity}

In the presence of surfactants, the highest reduction of proteolytic activity in the presence of ionic surfactants (SDS and CTAB) was observed during incubation with SDS; the peptidase maintained approximately $50 \%$ of activity in the presence of $0.02 \%$ SDS, but lost nearly all activity during incubation with $0.08 \%$ SDS. In the presence of CTAB, 20 and $10 \%$ relative activities were maintained at concentrations of 0.1 and $1 \%$, respectively. In contrast, nonionic surfactants did not present the same intense reduction of proteolytic activity, and the results showed approximately $60 \%$ of relative activity after incubation with $0.2 \%$ Triton X-100 or Tween 20 (Fig. 3a).

In studies using reducing agents, the peptidase showed residual activities of 50 and $40 \%$ following incubation with 100 or $150 \mathrm{mM}$ DTT, respectively. After incubation with the chaotropic agent guanidine, the enzyme maintained 

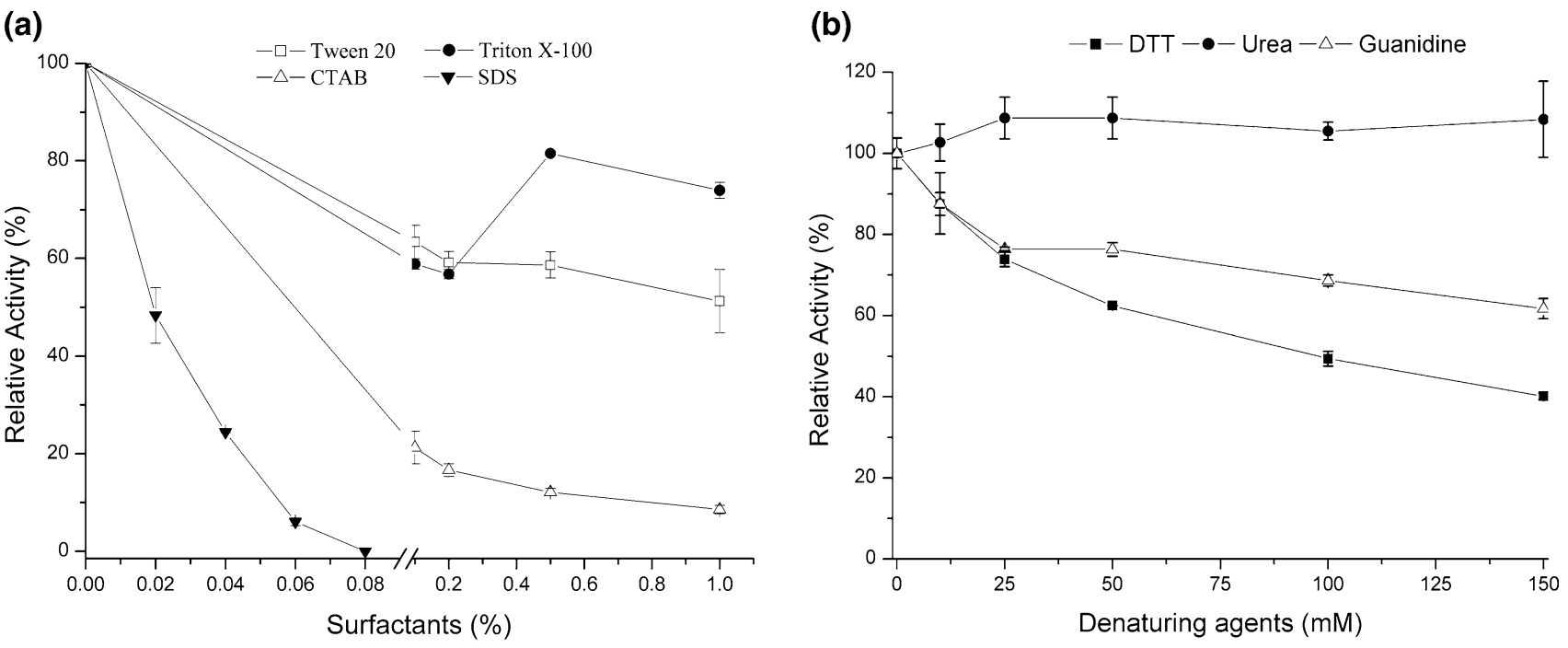

Fig. 3 Effects of surfactants (a) and denaturing agents (b) on the activity of the peptidase

approximately 70 and $60 \%$ of proteolytic activity at the same molar concentrations (100 and $150 \mathrm{mM}$, respectively). In addition, we did not observe interference of urea on proteolytic activity under the different concentrations assayed (Fig. 3b) that this compound had only very minor effects on cleavage of the hydrogen bond during protein folding. Statistical analysis demonstrated that there were no differences among all concentrations of urea $(p=0.86)$.

\section{Determination of the specificity of the peptidase}

Next, we analyzed the effects of the replacement of amino acids at specific positions in the substrate. For the primed side $\left(S_{1}^{\prime}, S_{2}^{\prime}\right.$, and $S_{3}^{\prime}$ subsites), we noted high hydrolysis with methionine $(\mathrm{M})$ and alanine $(\mathrm{A})$ at all subsites and moderate catalysis to glutamine $(\mathrm{Q})$ and valine $(\mathrm{V})$ when evaluated at $S^{\prime}{ }_{1}$ and $S^{\prime}{ }_{3}$ subsites. High catalytic efficiency values were observed by replacement with aromatic amino acids: $\mathrm{S}_{1}^{\prime}$ subsite (W and $\mathrm{Y}$ ); $\mathrm{S}_{2}^{\prime}$ subsite $\left(\mathrm{W}\right.$ and $\mathrm{Y}$ ); and $\mathrm{S}_{3}^{\prime}$ subsite ( $\mathrm{F}$ and $\mathrm{W})$, as shown in Table 2.

According to Table 2, basic amino acids were well accepted: $S_{1}^{\prime}(R), S_{2}^{\prime}(K$ and $R)$, and $S^{\prime}{ }_{3}(K$ and $R)$. In addition, the peptidase did not have high catalytic efficiency values for $\mathrm{D}$ and $\mathrm{E}$ (except $\mathrm{D}$ at $\mathrm{S}_{3}{ }_{3}$ ) and $\mathrm{P}$ and $\mathrm{G}$ (except $\mathrm{G}$ at $\mathrm{S}_{3}{ }_{3}$ and $\mathrm{P}$ at $\mathrm{S}_{2}{ }_{2}$ ) when evaluated on the primed side. However, in comparative analysis, despite low values of catalytic efficiency, it was possible to observed minor specificity at the $\mathrm{S}_{3}^{\prime}$ subsite, at which we observed moderate and high proteolytic activity for nonpolar, neutral polar, acidic, and basic amino acids.

At the unprimed side $\left(S_{1}, S_{2}\right.$, and $S_{3}$ subsites), we noted greater catalytic efficiency with basic amino acids, i.e., $\mathrm{R}\left(700 \mathrm{mM}^{-1} \mathrm{~s}^{-1}\right)$ and $\mathrm{K}\left(400 \mathrm{mM}^{-1} \mathrm{~s}^{-1}\right)$, and nonpolar aromatic amino acids, i.e., phenylalanine $\left(640 \mathrm{mM}^{-1} \mathrm{~s}^{-1}\right)$ at $\mathrm{S}_{1}$ (Table 3). According to the determination of the cleavage site, it was possible detected a hydrolysis point position offset when $R$ was replaced at the $S_{2}$ subsite; the displacement of $\mathrm{R}$ revealed the higher preference for hydrolysis between $\mathrm{R}$ and $\mathrm{R}$. We also observed subsite cooperativity, enabling a better enzyme-substrate interaction.

At the $\mathrm{S}_{2}$ subsite, we noted the highest preference for $\mathrm{G}$, $\mathrm{L}$, and $\mathrm{M}$ (amino acids with nonpolar side chains) as well as the neutral amino acids $\mathrm{N}$ and $\mathrm{T}$. At $\mathrm{S}_{3}$, high catalytic efficiency $\left(k_{\text {cat }} / K_{\mathrm{M}}\right)$ was not observed, but a preference was noted for the basic amino acids $\mathrm{K}\left(700 \mathrm{mM}^{-1} \mathrm{~s}^{-1}\right)$ and $\mathrm{R}$ $\left(350 \mathrm{mM}^{-1} \mathrm{~s}^{-1}\right)$, followed by I $\left(333.5 \mathrm{mM}^{-1} \mathrm{~s}^{-1}\right)$ (Table 3$)$.

Thus, the highest values for catalytic efficiency $\left(k_{\mathrm{cat}} / K_{\mathrm{M}}\right)$ and subsequent selectivity for enzymatic catalysis at the primed subsites were as follows: $\mathrm{M}\left(1250 \mathrm{mM}^{-1} \mathrm{~s}^{-1}\right)$ at $\mathrm{S}^{\prime}{ }_{1}, \mathrm{~K}\left(1294 \mathrm{mM}^{-1} \mathrm{~s}^{-1}\right), \mathrm{W}\left(1091 \mathrm{mM}^{-1} \mathrm{~s}^{-1}\right)$ at $\mathrm{S}_{2}^{\prime}$, and $\mathrm{M}$ $\left(1000 \mathrm{mM}^{-1} \mathrm{~s}^{-1}\right)$ at subsite $\mathrm{S}_{3}^{\prime}$.

As shown in Table 3, we also noted that among the various substrates evaluated in the study of subsite specificity, the enzyme showed high catalytic efficiency values when $\mathrm{F}$ and $\mathrm{M}$ were evaluated at $\mathrm{P}_{1}$ and $\mathrm{P}^{\prime}{ }_{1}$, respectively. Kinetic studies with the clotting sequence of $k$-casein using the fluorogenic substrate Abz-LSFMAIQ-EDDnp showed a high affinity for the peptidase $\left(K_{\mathrm{M}}=0.036\right)$, and the highest obtained value of catalytic efficiency $\left(4722 \pm 100 \mathrm{mM}^{-1} \mathrm{~s}^{-1}\right)$ was found for the specific hydrolysis of the peptide bond between $\mathrm{F}$ and M (Table 3). In addition, we also performed the clotting analysis using milk powder $(10 \% \mathrm{w} / \mathrm{v})$ and found that the specific activity of the aspartic peptidase was $5.5 \mathrm{U} /$ $\mu \mathrm{g}$ of enzyme. 
Table 2 Kinetic parameters for the hydrolysis of the series of FRET peptides $\left(\mathrm{S}_{1}^{\prime}, \mathrm{S}_{2}^{\prime}\right.$ and $\mathrm{S}_{3}^{\prime}$ subsites)

\begin{tabular}{|c|c|c|c|c|c|c|c|c|c|}
\hline \multirow[t]{2}{*}{$\mathrm{X}$} & \multicolumn{3}{|c|}{ Abz-KLRXSKQ-EDDnp $\left(\mathrm{P}_{1}^{\prime}\right)$} & \multicolumn{3}{|c|}{ Abz-KLRSXKQ-EDDnp $\left(\mathrm{P}_{2}^{\prime}\right)$} & \multicolumn{3}{|c|}{ Abz-KLRSSXQ-EDDnp $\left(\mathrm{P}_{3}^{\prime}\right)$} \\
\hline & $k_{\text {cat }}\left(\mathrm{s}^{-1}\right)$ & $K_{\mathrm{M}}(\mu \mathrm{M})$ & $\begin{array}{l}k_{\mathrm{cat}} / K_{\mathrm{M}} \\
\left(\mathrm{mM}^{-1} \mathrm{~s}^{-1}\right)\end{array}$ & $k_{\text {cat }}\left(\mathrm{s}^{-1}\right)$ & $K_{\mathrm{M}}(\mu \mathrm{M})$ & $\begin{array}{l}k_{\mathrm{cat}} / K_{\mathrm{M}} \\
\left(\mathrm{mM}^{-1} \mathrm{~s}^{-1}\right)\end{array}$ & $k_{\mathrm{cat}}\left(\mathrm{s}^{-1}\right)$ & $K_{\mathrm{M}}(\mu \mathrm{M})$ & $\begin{array}{l}k_{\mathrm{cat}} / K_{\mathrm{M}} \\
\left(\mathrm{mM}^{-1} \mathrm{~s}^{-1}\right)\end{array}$ \\
\hline A & $0.67 \pm 0.002$ & $1.15 \pm 0.06$ & $582.5 \pm 29$ & $0.4 \pm 0.006$ & $0.5 \pm 0.01$ & $800 \pm 33$ & $0.085 \pm 6.7$ & $0.14 \pm 0.08$ & $607 \pm 36$ \\
\hline $\mathrm{D}$ & $0.04 \pm 0.002$ & $1.3 \pm 0.05$ & $34.5 \pm 1.6$ & $0.17 \pm 0.007$ & $0.9 \pm 0.06$ & $189 \pm 15$ & $0.04 \pm 1.6$ & $0.1 \pm 0.002$ & $400 \pm 46$ \\
\hline $\mathrm{E}$ & $0.25 \pm 0.005$ & $2.8 \pm 0.06$ & $89 \pm 2$ & $0.15 \pm 0.002$ & $1.7 \pm 0.2$ & $88 \pm 5$ & $0.015 \pm 0.1$ & $0.1 \pm 0.003$ & $150 \pm 14$ \\
\hline $\mathrm{F}$ & $0.17 \pm 0.001$ & $0.5 \pm 0.03$ & $340 \pm 29$ & $0.085 \pm 0.005$ & $1 \pm 0.08$ & $85 \pm 6.8$ & $0.026 \pm 1$ & $0.04 \pm 0$ & $650 \pm 15$ \\
\hline G & $0.066 \pm 0.002$ & $2.5 \pm 0.1$ & $26.5 \pm 0.6$ & $0.1 \pm 0.007$ & $1.5 \pm 0.12$ & $66.5 \pm 5$ & $0.065 \pm 6.8$ & $0.08 \pm 0$ & $812.5 \pm 5$ \\
\hline $\mathrm{H}$ & $0.85 \pm 0.07$ & $2.3 \pm 0.06$ & $369.5 \pm 36$ & $0.4 \pm 0.011$ & $1.5 \pm 0.01$ & $266.5 \pm 2.5$ & \multicolumn{3}{|c|}{ No determined } \\
\hline I & $0.1 \pm 0.007$ & $0.2 \pm 0.02$ & $500 \pm 16$ & $0.03 \pm 0.0006$ & $0.1 \pm 0.001$ & $300 \pm 16$ & $0.05 \pm 1.4$ & $0.3 \pm 0.01$ & $166.5 \pm 27$ \\
\hline K & No determined & & & $1.1 \pm 0.07$ & $0.85 \pm 0.05$ & $1,294 \pm 37$ & $0.035 \pm 0$ & $0.5 \pm 0.01$ & $700 \pm 5$ \\
\hline $\mathrm{L}$ & No determined & & & $1 \pm 0.08$ & $1.7 \pm 0.08$ & $588 \pm 28.5$ & \multicolumn{3}{|c|}{ No hydrolysis } \\
\hline M & $0.5 \pm 0.03$ & $0.4 \pm 0.04$ & $1250 \pm 72$ & $0.28 \pm 0.01$ & $0.3 \pm 0.02$ & $933.5 \pm 64$ & $0.045 \pm 2.5$ & $0.045 \pm 0$ & $1,000 \pm 47$ \\
\hline $\mathrm{N}$ & No determined & & & $0.45 \pm 0.004$ & $1.5 \pm 0.15$ & $300 \pm 26$ & \multicolumn{3}{|c|}{ No determined } \\
\hline $\mathrm{P}$ & $0.040 \pm 0.003$ & $1.7 \pm 0.15$ & $23.5 \pm 1$ & $0.28 \pm 0.002$ & $0.7 \pm 0.05$ & $400 \pm 29$ & $0.025 \pm 2$ & $1 \pm 0.03$ & $25 \pm 3$ \\
\hline Q & $0.27 \pm 0.003$ & $0.5 \pm 0.01$ & $540 \pm 17$ & $0.027 \pm 0.002$ & $0.1 \pm 0.002$ & $270 \pm 23$ & $0.03 \pm 1.2$ & $0.06 \pm 0$ & $500 \pm 14$ \\
\hline $\mathrm{R}$ & $1.2 \pm 0.08$ & $1.5 \pm 0.15$ & $800 \pm 27$ & $0.9 \pm 0.08$ & $1 \pm 0.004$ & $900 \pm 28$ & $0.15 \pm 2$ & $0.3 \pm 0.007$ & $500 \pm 45$ \\
\hline S & $0.35 \pm 0.002$ & $0.5 \pm 0.01$ & $700 \pm 5$ & $0.35 \pm 0.002$ & $0.5 \pm 0.01$ & $700 \pm 5$ & $0.13 \pm 17$ & $0.4 \pm 0.03$ & $325 \pm 21$ \\
\hline V & $0.1 \pm 0.005$ & $0.2 \pm 0.003$ & $500 \pm 8$ & $0.04 \pm 0.003$ & $0.4 \pm 0.01$ & $100 \pm 7$ & $0.035 \pm 2$ & $0.07 \pm 0$ & $500 \pm 66$ \\
\hline W & $0.15 \pm 0.006$ & $0.15 \pm 0.06$ & $1000 \pm 65$ & $0.12 \pm 0.002$ & $0.11 \pm 0.08$ & $1091 \pm 76$ & $0.02 \pm 1$ & $0.03 \pm 0$ & $666.5 \pm 43$ \\
\hline Y & $1.1 \pm 0.04$ & $2 \pm 0.07$ & $550 \pm 20$ & $0.6 \pm 0.04$ & $1 \pm 0.006$ & $600 \pm 3.5$ & $0.05 \pm 1$ & $0.15 \pm 0.01$ & $333.5 \pm 31$ \\
\hline
\end{tabular}

Hydrolysis conditions: $100 \mathrm{mM}$ acetate buffer $\mathrm{pH} 5.5$ at $50{ }^{\circ} \mathrm{C}$. Values are the average of three independent experiments \pm standard deviations. All peptides present only one cleaved point, have been at $\mathrm{R} \downarrow S$ or $\mathrm{R} \downarrow \mathbf{X}(100 \%)$, except Abz-KL $\downarrow R \downarrow \mathbf{R} \downarrow$ SKQ-EDDnp, in whose preference on hydrolisys point was at $\mathrm{L} \downarrow \mathrm{R}(16 \%) ; \mathrm{R} \downarrow \mathrm{R}(32 \%)$ and $\mathrm{R} \downarrow \mathrm{S}(52 \%)$

Taken together, our results confirmed the relevance of this peptidase for the clotting of milk, with greater coagulant activity than proteolytic activity.

\section{Discussion}

$R$. miehei is a thermophilic filamentous fungus that is known for its ability to produce aspartic peptidase with suitable biochemical properties for industrial applications, e.g., in cheese manufacturing (milk-clotting activity), peptide synthesis, decolorization of fish meat (Katsuobushi), and degradation of the turbidity of proteins in juices and alcoholic liquors [1, 29]. In this study, we purified and characterized the aspartic peptidase from $R$. miehei to facilitate the industrial application of peptidases with relevant biochemical properties, particularly for cheese manufacturing. Our results provided important insights into the optimal purification methods and reaction conditions for the aspartic peptidase from this fungus.

Chromatography is an important methodology for the study of peptidases under homogeneous conditions and is often used to evaluate the biochemical properties of a protein. In this study, we carried out peptidase purification using a quick and easy chromatographic method. In addition, we achieved high yields after concentration of crude extract obtained to chromatography; this process is thought to be more feasible than precipitation using organic solvents or a saline gradient, as described by other researchers in fungal peptidases $[10,17]$.

Notably, the aspartic peptidase described in this study showed more thermal stability than that of a similar peptidase (rhizopuspepsin) reported by Hsiao et al. [12] produced by Rhizopus oryzae, whose maximum activity was observed at $75{ }^{\circ} \mathrm{C}$, with substantially reduced relative activity (approximately $50 \%$ ) after $30 \mathrm{~min}$ at $45^{\circ} \mathrm{C}$.

We also noted negative modulation by metal ions, particularly aluminum chloride and copper (II) chloride. Interestingly, the aspartic peptidase described in this work showed decreased activity in the presence of copper (II) ions, in contrast to the results of other studies of aspartic peptidases, for which $\mathrm{Cu}^{2+}$ has been shown to promote enzyme activation [29]. Negative modulation of proteolytic activity by aluminum chloride [5, 9] and copper (II) ions [19] has also been reported by other researchers in different fungal peptidases.

Similarly, we found that surfactants, DTT, urea, and guanidine also affected proteolytic activity. Negative modulation of the enzymatic reaction can be induced by: surfactants, due to the interference of hydrophobic 


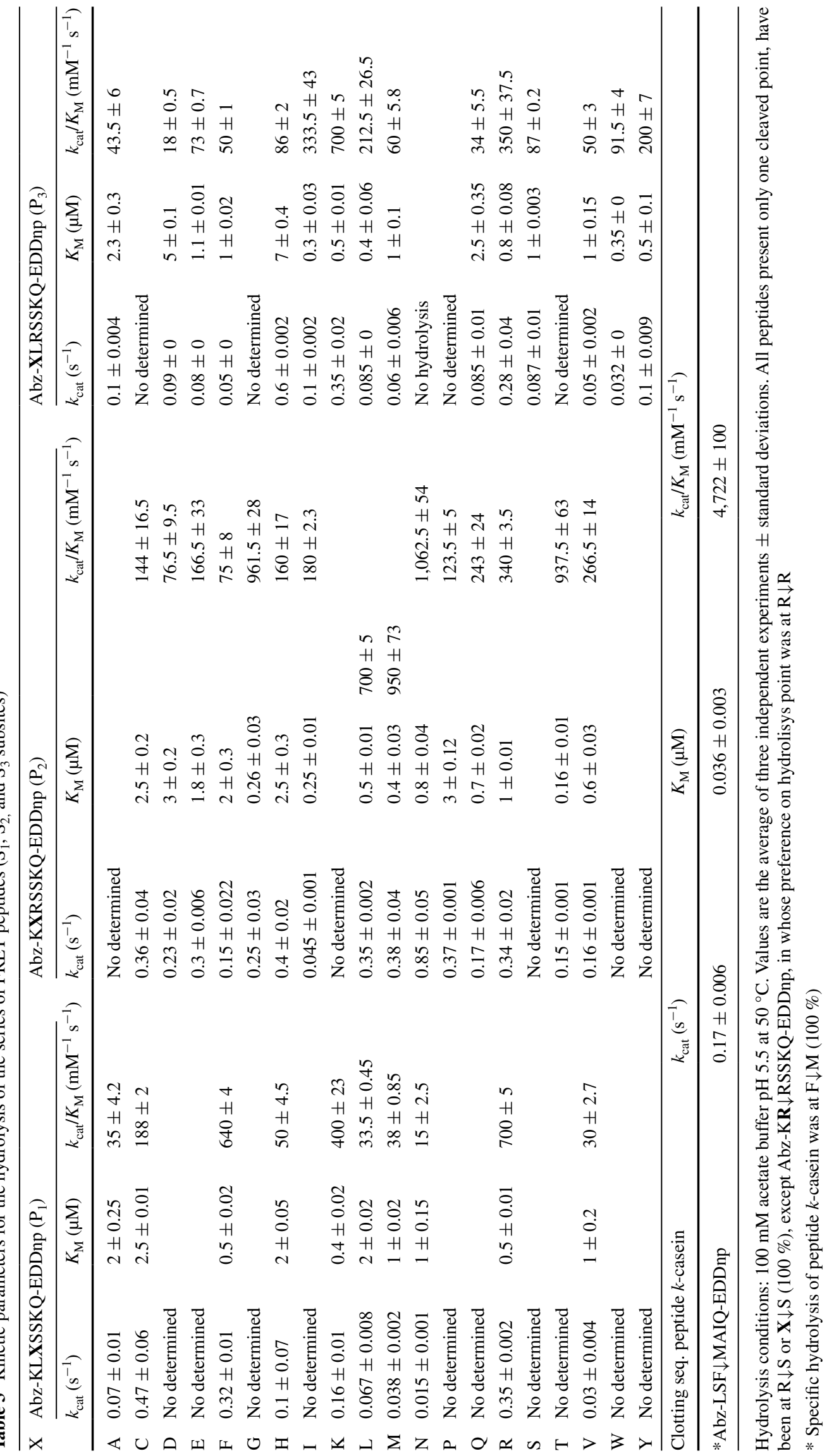


interactions; DTT is a reducing agent that reduces the disulfide bond ( $\mathrm{S}-\mathrm{S})$ between two cysteine residues on a polypeptide chain, whereas urea and guanidine are chaotropic agents that affect hydrogen bonds. All of these chemical agents alter the intramolecular forces that function to maintain the molecular arrangement. Thus, the action of these chemical compounds can modify the protein structure (denaturation) and result in reduction or loss of proteolytic activity.

Our results suggested that the hydrophobic interactions and disulfide bonds within the molecular structure of the peptidase were dramatically affected, particularly by SDS and DTT, which greatly reduced catalytic performance. Similar results for SDS were reported in a previous study $[5,9]$. Notably, while urea did not affect proteolytic activity, guanidine appeared to have greater effects on the disruption of hydrogen bonds, resulting in more extensive denaturation. This result may be explained by the differences in charges between these chemical compounds; guanidine is a strong cationic chaotropic agent, and urea is a chaotropic agent that is not charged.

From our characterization of the catalytic efficiency of the peptidase, we found that this aspartic peptidase exhibited strong hydrolysis of nonpolar amino acids, particularly M; basic amino acids, i.e., H, K, and R; and aromatic residues, i.e., F, W, and Y. The peptidase had low preference for the acidic amino acids $\mathrm{D}$ and $\mathrm{E}$, except for $\mathrm{D}$ at the $\mathrm{S}_{3}^{\prime}$ subsite. These results are generally consistent with the results of other studies of human [4] and fungal aspartic peptidases [22]. Moreover, our results also showed the capacity of the peptidase to promote milk clotting using milk powder, with specific hydrolysis between amino acids $\mathrm{F}$ and $\mathrm{M}$ and a high affinity for the peptide $k$-casein substrate. Interestingly, this peptidase exhibited higher coagulant activity than proteolytic activity, and the observed specificity for cleavage of the peptide bond between $\mathrm{Phe}^{105}-\mathrm{Met}^{106}$, which is a key step in the coagulation of milk during the preparation of cheese, would facilitate the use of the purified enzyme in this industrial process. Further studies are needed to examine the mode of action of this peptidase for different protein substrates, which will be crucial for the application of this enzyme in industrial processes.

In summary, we have purified a fungal aspartic peptidase that could be easily purified and exhibited optimal biochemical properties for industrial applications. We also provided a comprehensive mapping of the catalytic subsites of this aspartic peptidase, for the first time. Using various substrates with a series of FRET peptides (Abz$\mathrm{P}_{3} \mathrm{P}_{2} \mathrm{P}_{1} \mathrm{P}_{1}^{\prime} \mathrm{P}_{2}{ }_{2} \mathrm{P}_{3} \mathrm{Q}$-EDDnp) and clotting $k$-casein (AbzLSFMAIQ-EDDnp) as the substrate, we found that the peptidase exhibited a clear specificity for cleaving certain peptide bonds and that the coagulant activity of this enzyme was higher than its proteolytic activity, demonstrating its potential for industrial applications, such as peptide synthesis, casein hydrolysates, and specially to cheese production.

Acknowledgments The authors would like to acknowledge the financial support provided by Fundação de Amparo à Pesquisa do Estado de São Paulo-FAPESP (2011/06986-0 and 2012/24703-8) and Conselho Nacional de Desenvolvimento Científico e Tecnológico (308078/2012-8).

\section{References}

1. Aoki K, Matsubara S, Umeda M, Tachibanac S, Doi M, Takenaka S (2013) Aspartic protease from Aspergillus (Eurotium) repens strain MK82 is involved in the hydrolysis and decolourisation of dried bonito (Katsuobushi). J Sci Food Agric 93:1349-1355

2. Bersanetti PA, Park HY, Bae KS, Son KH, Shin DH, Hirata IY, Juliano MA, Carmona AK, Juliano L (2005) Characterization of arazyme, an exocellular metalloprotease isolated from Serratia proteamaculans culture medium. Enzyme Microb Tech 37:574-581

3. Bradford MM (1976) A rapid and sensitive method for the quantitation of microgram quantities of protein-dye binding. Anal Biochem 72:248-254

4. Brinkworth RI, Prociv P, Loukas A, Brindley PJ (2001) Hemoglobin-degrading, aspartic proteases of blood-feeding parasites: substrate specificity revealed by homology models. J Biol Chem 42:38844-38851

5. Da Silva RR, Caetano RC, Okamoto DN, de Oliveira LCG, Bertolin TC, Juliano MA, Juliano L, Oliveira AHC, Rosa JC, Cabral $\mathrm{H}$ (2014) The identification and biochemical properties of the catalytic specificity of a serine peptidase secreted by Aspergillus fumigatus Fresenius. Protein Pept Lett 21:663-671

6. De Oliveira AHC, Cruz AK, Greene LJ, Rosa JC, Ward RJ (2006) Subproteomic analysis of soluble proteins of the microsomal fraction from two Leishmania species. Comp Biochem Physiol Part D 3:300-308

7. Dunn BM (1989) Determination of protease mechanism. In: Beynon RJ, Bond JS (eds) Proteolytic enzymes: a practical approach. IRL Press, NY, pp 57-81

8. El-Enshasy HA (2007) Filamentous fungal cultures-process characteristics, products, and applications. In: Shang-Tian Y (ed) Bioprocessing for Value-Added Products from Renewable Resources. Elsevier BV, pp 225-262

9. Graminho ER, Silva RR, Cabral TPF, Arantes EC, da Rosa NG, Juliano L, Okamoto DN, Oliveira LCG, Kondo MY, Juliano MA, Cabral H (2013) Purification, characterization, and specificity determination of a new serine protease secreted by Penicillium waksmanii. Appl Biochem Biotechnol 169:201-214

10. Hajji M, Kanoun S, Nasri M, Gharsallah N (2007) Purification and characterization of an alkaline serine-protease produced by a new isolated Aspergillus clavatus ES1. Process Biochem 42:791-797

11. Hirata IY, Cezari MHS, Nakaie CR, Boschcov P, Ito AS, Juliano MA, Juliano L (1994) Internally quenched fluorogenic protease substrates: Solid-phase synthesis and fluorescence spectroscopy of peptides containing ortho-aminobenzoyl/dinitrophenyl groups as donor-acceptor pairs. Lett Pept Sci 1:299-308

12. Hsiao N-W, Chen Y, Kuan Y-C, Lee Y-C, Lee S-K, Chan H-H, Kao C-H (2014) Purification and characterization of an aspartic protease from the Rhizopus oryzae protease extract, Peptidase R. Electron J Biotechnol 17:89-94

13. Klemencic I, Carmona AK, Cezari MHS, Juliano MA, Juliano L, Guncar G, Turk D, Krizaj I, Turk V, Turk B (2000) Biochemical 
characterization of human cathepsin $\mathrm{X}$ revealed that the enzyme is an exopeptidase, acting as carboxymonopeptidase or carboxydipeptidase. Eur J Biochem 267:5404-5412

14. Kumar A, Grover S, Sharma J, Batish VK (2010) Chymosin and other milk coagulants: sources and biotechnological interventions. Crit Rev Biotechnol 30:243-258

15. Laemmli UK (1970) Cleavage of structural proteins during the assembly of the head of bacteriophage T4. Nature 227:680-685

16. Merheb-Dini C, Gomes E, Boscolo M, da Silva R (2010) Production and characterization of a milk-clotting protease in the crude enzymatic extract from the newly isolated Thermomucor indicae-seudaticae N31 (Milk-clotting protease from the newly isolated Thermomucor indicae-seudaticae N31). Food Chem 120:87-93

17. Merheb-Dini C, Cabral H, Leite RSR, Zanphorlin LM, Okamoto DN, Rodriguez GOB, Juliano L, Arantes EC, Gomes E, Da Silva $R$ (2009) Biochemical and functional characterization of a metalloprotease from the thermophilic fungus Thermoascus aurantiacus. J Agr Food Chem 57:9210-9217

18. Meyers SP, Ahearn DG (1977) Extracellular proteolysis by Candida lipolytica. Mycologia 69:646-651

19. Neto YAAH, de Oliveira LCG, de Oliveira AHC, Rosa JC, Juliano MA, Juliano L, Rodrigues A, Cabral H (2015) Determination of specificity and biochemical characteristics of neutral protease isolated from Myceliophthora thermophila. Protein Pept Lett 22:972-982

20. Silva RR, Angelo T, Cabral H (2013) Comparative evaluation of peptidases produced by Penicillium corylophilum and Penicillium waksmanii in solid state fermentation using agro-industrial residues. J Agric Sci Technol B 3:230-237

21. Ramão A, Gimenez M, Laure HJ, Izumi C, Vida RC, ObaShinjo S, Marie SK, Rosa JC (2012) Changes in the expression of proteins associated with aerobic glycolysis and cell migration are involved in tumorigenic ability of two glioma cell lines. Proteome Sci 53:1-12. doi:10.1186/1477-5956-10-53

22. Rao S, Mizutani O, Hirano T, Masaki K, Lefuji H (2011) Purification and characterization of a novel aspartic protease from basidiomycetous yeast Cryptococcus sp. S-2. J Biosci Bioeng 112:441-446

23. Rao MB, Tanksale AM, Ghatge MS, Deshpande VV (1998) Molecular and biotechnological aspects of microbial proteases. Microbiol Mol Biol Rev 62:597-635

24. Sarath G, de la Motte RS, Wagner FW (1996) Protease assay methods. In: Beynon RJ, Bond JS (eds) Proteolytic enzymes: a practical approach. IRL Press, NY, pp 25-55

25. Schechter I, Berger A (1967) On the size of the active site in proteases. I. Papain. Biochem Bioph Res Co 27:157-162

26. See YS, Jackowski G (1989) Estimating molecular weights of polypeptides by SDS gel electrophoresis. In: Creigton TE (ed) Protein structure a practical approach. Oxford University, New York, pp 1-19

27. Silva RR, Cabral TPF, Rodrigues A, Cabral H (2013) Production and partial characterization of serine and metallo peptidases secreted by Aspergillus fumigatus Fresenius in submerged and solid state fermentation. Braz J Microbiol 44:235-243

28. Turk B, Kriz Ïaj I, Kralj B, Dolenc I, Popovic ÏT, Bieth JG, Turk V (1993) Bovine stefin C, a new member of the stefin family. J Biol Chem 268:7323-7329

29. Yegin S, Fernandez-Lahore M, Salgado AJG, Guvenc U, Goksungur Y, Tari C (2011) Aspartic proteinases from Mucor spp. in cheese manufacturing. Appl Microbiol Biotechnol 89:949-960 